\title{
The Storage Stability of Anthocyanins in Mao (Antidesma thwaitesianum Müll. Arg.) Juice and Concentrate
}

\author{
Arunya Prommakool ${ }^{1, a}$, Kriangkrai Phattayakorn ${ }^{1}$ \\ ${ }^{1}$ Kasetsart University, Chalermphrakiat Sakon Nakhon Province Campus, Thailand
}

\begin{abstract}
Mao or Makmao (Antidesma thwaitesianum Müll. Arg.) is a wild plant found in the northeast of Thailand. Mao is one of fruits which are source of anthocyanins. Mao fruits are used for juice and concentrate which are consumed for healthy drinks. Determination of the kinetic parameters is essential to predict the quality changes and stability of anthocyanins in Mao juice and concentrate that occur during storage. The purpose of this research was to study the degradation of anthocyanins in Mao juice and concentrate during storage at 5, 30 and $37^{\circ} \mathrm{C}$ for 15 days. The storage stability of Mao anthocyanins was studied in $15^{\circ}$ Brix juice and $45^{\circ}$ Brix concentrate. The degradation kinetic $(\mathrm{k})$, half-life $\left(\mathrm{t}_{1 / 2}\right)$, activation energy $\left(\mathrm{E}_{\mathrm{a}}\right)$ and $\mathrm{Q}_{10}$ values for Mao anthocyanins degradation were determined. The results indicated that analysis of kinetic data for the degradation of anthocyanins followed a first-order reaction. An increase storage temperature from 5 to 30 and $37^{\circ} \mathrm{C}$ increased $\mathrm{k}$ value of anthocyanins in Mao juice and concentrate. Increasing storage temperature decreased $t_{1 / 2}$ value of anthocyanins in both concentrations. At 5,30 and $37^{\circ} \mathrm{C}$, the $t_{1 / 2}$ of anthocyanins decreased from 35 to 13 and 5 days for Mao juice and 32 to 25 and 21 days for Mao concentrate. The $E_{a}$ value of the anthocyanins degradation in Mao juice and concentrate were 38.03 and $8.42 \mathrm{~kJ} / \mathrm{mol}$, respectively. $Q_{10}$ values of both Mao juice and concentrate at $30-37^{\circ} \mathrm{C}$ were higher than those were storaged at $5-30^{\circ} \mathrm{C}$. Thus higher stability of anthocyanins was achieved by using concentration and storage at lower temperature.
\end{abstract}

\section{Introduction}

Mao or Makmao (Antidesma thwaitesianum Müll. Arg.) is a wild plant found in the northeast of Thailand. However, Mao plant also grows well in Africa, Australia, tropical Asia and islands in the Pacific Oceans. Mao is one of fruits which are source of anthocyanins and antioxidants [1-3]. Mao fruits are used for juice and concentrate which are consumed for healthy drinks and theirs have become more popular in Thailand.

Anthocyanins are a good source of natural antioxidant, in addition, anthocyanins have been reported to be highly effective in reducing cholesterol levels in the human body including preventing cardiovascular diseases and anticarcinogenic activity [4, 5]. Anthocyanins are natural pigments which are responsible for the attractive red, purple and blue colors in Mao fruits. However, anthocyanin are rather unstable during processing and storage, which readily degrade and form colorless or undesirable brown-colored compounds [6, 7]. Temperature, time, solid content and storage conditions are considered to be important factors influencing its stability [8].

In previous studies, thermal and storage degradation kinetics of fruits and their products have been reported. Kirca and Cemeroğlu [9] studied stability of anthocyanins in blood orange juice and concentrate. They found that anthocyanin degradation followed a first-order reaction with the activation energies $\left(\mathrm{E}_{\mathrm{a}}\right)$ ranged from $73-$ $89 \mathrm{~kJ} \mathrm{~mol}^{-1}$. Wang and $\mathrm{Xu}[10]$ indicated that thermal degradation of blackberry anthocyanins at $60-90{ }^{\circ} \mathrm{C}$ followed first-order reaction kinetics with $E_{a}$ value of anthocyanin degradation was $59 \mathrm{~kJ} \mathrm{~mol}^{-1}$ for blackberry juice. In addition, Kirca et al. [8] studied stability of black carrot anthocyanins during storage at $4-37{ }^{\circ} \mathrm{C}$. The studied resulted the degradation fitted a first-order reaction with $E_{a}$ values ranged from $62-86 \mathrm{~kJ} \mathrm{~mol}^{-1}$. The anthocyanins decreased with increasing solid content during storage. Similarly, Kara and Erçelebi [11] reported the degradation of anthocyanins in Urmu mulberry showed a first-order reaction as well as the degtadation of anthocyanins in blood orange juice [12]. Hellström et al. [13] studied the stability of anthocyanins in Chokeberry, Blackcurrant, Crowberry and Mixed Berry juice stored at 4, 9 and $21{ }^{\circ} \mathrm{C}$. The results suggested that anthocyanins stability affected by type of anthocyanin, the origin of the juice and especially the storage temperature. The $t_{1 / 2}$ value of anthocyanins was much shorter at room temperature than at cold storage.

Determination of the kinetic parameters is essential to predict the quality changes that occur during storage. However, a study of storage stability of anthocyanains in Mao juice and concentrate has never been reported. Therefore, the objective of our study was to determine the stability of anthocyanins in Mao juice and concentrate during storage at various temperatures.

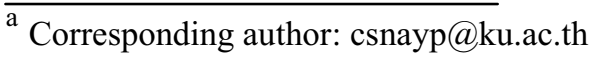




\section{Materials and Methods}

\subsection{Preparation of Mao juice and concentrate}

Fruits of Mao (Antidesma thwaitesianum Mull. Arg) at a commercially mature stage were purchased from a local market in SakonNakhon, Thailands. The fruits were homogeneously with a blender and filtered through cheesecloth to remove pulp. $60^{\circ}$ Brix of sucrose solution were added to the juice gave the finally concentration to $15^{\circ}$ Brix. The juice was concentrated to $45^{\circ}$ Brix by rotary evaporator (BUCHI Rotavapor R-114 model, Switzerland) at $60^{\circ} \mathrm{C}$. The pasteurization of the juice and concentrate were carried out at $85^{\circ} \mathrm{C}$ for $15 \mathrm{~min}$ transferred to sterile glass bottles and followed by rapid cooling in tap water.

\subsection{The study of storage stability and degradation kinetic of anthocyanins in Mao juice and concentrate}

The storage stability of Mao anthocyanins was studied in $15^{\circ}$ Brix juice and $45^{\circ}$ Brix concentrate. The Aqueous of $10 \mathrm{~mL}$ Mao juice and concentrate were put into screwcap test tubes and then incubated at 5,30 and $37^{\circ} \mathrm{C}$ for 15 days. Degradation kinetic of anthocyanins was analyzed. The zero and first order reaction rate constant $(\mathrm{k})$ was calculated by the following equations [14]:

$$
\begin{gathered}
Q_{t}=Q_{0^{-}} k t_{s} \\
\ln \left(Q_{t} / Q_{0}\right)=-k t_{s}
\end{gathered}
$$

Where $k$ is the rate constant $\left(\right.$ day $\left.^{-1}\right), Q_{t}$ is the anthocyanins content after $t$ day of storage at a given temperature, $\mathrm{Q}_{0}$ is the initial anthocyanin content, $t_{s}$ is time (day).

$k$ value was calculated from the slope of the straight lines given by equation ( 1 or 2 ), using a linear regression procedure of the sigmaplot.

Half life $\left(t_{1 / 2}\right)$ which is the times needed for $50 \%$ degradation of anthocyanins was calculated by the following equations:

$$
\begin{gathered}
t_{1 / 2}=Q_{0} / 2 k \\
t_{1 / 2}=-\ln 0.5 / k
\end{gathered}
$$

The dependence of the degradation of Mao anthocyanins on temperature was determined by calculating the activation energy $\left(E_{a}\right)$ and Temperature coefficient $\left(Q_{10}\right)$ value from the following equation:

$$
\begin{gathered}
k=k_{0} x e^{-E a / R T} \\
Q_{10}=\left(k_{2} / k_{1}\right)^{10 /\left(T_{2}-T\right)}
\end{gathered}
$$

Where $k_{0}$ is the frequency factor $\left(\right.$ day $\left.^{-1}\right), E_{a}$ is activation energy $(\mathrm{J} / \mathrm{mol}), R$ is the universal gas contant $(8.314 \mathrm{~J} / \mathrm{mol} \mathrm{K})$ and $T$ is the absolute temperature (Kelvin, $\mathrm{K})$.

The $E_{a}$ value was calculated from the slope of the straight lines given by equation (5), using a linear regression procedure of the sigmaplot.

\subsection{Determination of anthocyanins}

The total anthocyanin content was determined by the $\mathrm{pH}$ differential method [10] using two buffer systems; 0.025 $\mathrm{M}$ potassium chloride $(\mathrm{KCl})$ buffer at $\mathrm{pH} 1.0$ and $0.4 \mathrm{M}$ sodium acetate $\left(\mathrm{NaC}_{2} \mathrm{H}_{3} \mathrm{O}_{2}\right)$ buffer at $\mathrm{pH} 4.5$. A $0.1 \mathrm{ml}$ of sample was transferred to $10 \mathrm{ml}$ volumetric flash and made up to $10 \mathrm{ml}$ with corresponding buffer and the absorbance was masured at 510 and $700 \mathrm{~nm}$. The total anthocyanins were calculated as cyanindin-3-gluciside according to the following equation:

$\underset{(\mathrm{m} g / \mathrm{L})}{\text { Total anthocyanins }}=\frac{\text { AxMWxDFx1000 }}{\varepsilon \times l}$

Where $A=\left(A_{510}-A_{700}\right)_{p H 1.0}-\left(A_{510}-A_{700}\right)_{p H 4.5} ; M W=$ $449.2 \mathrm{~g} / \mathrm{mol}$ for cyaniding-3-glucoside; $D F=$ dilution factor; $l=$ pathlength in $\mathrm{cm} ; \varepsilon=26,900$ molar extinction coefficient in $\mathrm{L} / \mathrm{mol} / \mathrm{cm}$ for cyaniding-3-glucoside; $1000=$ conversion from $\mathrm{g}$ to $\mathrm{mg}$. All analyses were done in triplicate $(n=3)$.

\subsection{Determination of antioxidant activity}

The antioxidant activity of juice was evaluated using the stable radical DPPH, according to the method of Deng et al. [15]. Briefly, $0.1 \mathrm{ul}$ of the juice was transferred into a test tube and then mixed thoroughly with $5 \mathrm{ml}$ of DPPH solution (1.0 mM in methanol). After incubation for 40 min, the absorbance of the mixtures at $517 \mathrm{~nm}$ was determined using spectrophotometer. The percentage of DPPH radical scavenging activity of juice was calculated as:

DPPH scavenging effect $(\%)=\left(\frac{A b s_{0}-A b s_{1}}{A b s_{0}}\right) X 100$

Where $\mathrm{Abs}_{0}=$ absorbance value of control sample; $\mathrm{Abs}_{1}=$ absorbance value of Mao juice

\subsection{Other analyses}

Total soluble solid was used a refractometer (Atogo, Tokyo, Japan). The $\mathrm{pH}$ was measured by $\mathrm{pH}$ meter (Methohm IKA-MF10basic, Germany)

\subsection{Statistical analysis}

Data was analyzed by one-way analysis of variance (ANOVA) with the application of SPSS software version 10.0.1 (SPSS Inc., Chicago, USA) at 5\% significance level.

\section{Results and Discussion}

The total soluble solid, $\mathrm{pH}$, anthocyanin content and antioxidant activity of Mao juice and concentrate showed in Table 1. It was found that there was the loss of anthocyanins during concentration process $(p \leq 0.05)$. The loss of anthocyanins due to retention time of concentration more than 3 hours. Wang and $\mathrm{Xu}$ [10] 
reported that there was less than 5\% loss of anthocyanins from the concentration step. The time was needed for juice concentration was less than $100 \mathrm{~min}$ at $60{ }^{\circ} \mathrm{C}$. The oxidation activity of Mao juice and concentrate were not significantly affect $(\mathrm{p}>0.05)$.

Table 1: Chemical composition of Mao juice and concentrate

\begin{tabular}{|c|c|c|c|c|}
\hline Sample & $\begin{array}{c}\text { Total } \\
\text { soluble } \\
\text { solid } \\
\left({ }^{\circ} \text { Brix }\right)\end{array}$ & $\mathrm{pH}$ & $\begin{array}{c}\text { Anthocyanin } \\
\text { content } \\
(\mathrm{mg} / \mathrm{L})\end{array}$ & $\begin{array}{c}\text { Antioxicant } \\
\text { activity } \\
(\%)\end{array}$ \\
\hline Juice & $15^{\mathrm{b}} \pm 0.41$ & $2.94^{\mathrm{b}} \pm 0.28$ & $33.48^{\mathrm{a}} \pm 2.01$ & $87.98^{\mathrm{a}} \pm 2.25$ \\
\hline Concentrate & $45^{\mathrm{a}} \pm 0.37$ & $3.52^{\mathrm{a}} \pm 0.69$ & $23.21^{\mathrm{b}} \pm 0.94$ & $89.69^{\mathrm{a}} \pm 0.80$ \\
\hline
\end{tabular}

Mean values within a column superscripted by the same letter are not significantly different at $\mathrm{P}<0.05$.

\subsection{Stability of anthocyanins during storage}

The degradation of anthocyanins from Mao juice and concentrate was studied during storage at 5,30 and $37{ }^{\circ} \mathrm{C}$. The anthocyanins content from Mao juice and concentrate were plotted as a function of time (Figure 1 and 2). It showed that storage temperature affected on degradation of anthocyanins. The results clearly indicated that anthocyanin degradation increased with increasing storage temperature and time. An increase in temperature might be attributed to the degradation of anthocyanin from juice and concentrate. Anthocynains are a bioactive compound which can be reduced due to heated degradation. Mao juice anthocyanins were faster degradation as compared to concentrate.

Anthocyanin contents during storage decreased with increasing temperature and time. Linear regression confirmed that the degradation of anthocyanins in Mao juice and concentrate followed by a first-order reaction. Previous studies showed that degradation of anthocyanins in many juice and their products followed a first-order reaction $[7,10-13,16]$.

The kinetic parameters of anthocyanins degradation in Mao juice and concentrate are shown in Table 2 . The $\mathrm{k}$ value varies between $(2-13.2) \times 10^{-2}$ and $(2.2-3.3) \times 10^{-2}$ day $^{-1}$ for juice and concentrate, respectively. The $t_{1 / 2}$ values at 5,30 and $37^{\circ} \mathrm{C}$ were calculated as 35,13 and 5 days for juice samples and 32, 25 and 21 days for concentrate samples, respectively. The results revealed that anthocyanins in Mao concentrate are more stable than juice during storage at 30 and $37{ }^{\circ} \mathrm{C}$. The storage at 30 and $37^{\circ} \mathrm{C}$ resulted in a much faster anthocyanin degradation as compared to storage at $5^{\circ} \mathrm{C}$. Thus, an increase of storage temperature trends to increased degradation rate while as $t_{1 / 2}$ values decreased. These results were somewhat similar to the results of Wang and $\mathrm{Xu}$ [10] who studied anthocyanin degradation in blackberry juice and concentrate over the tempature ranged within $5-37^{\circ} \mathrm{C}$. The results found that increasing anthocyanin degradation incresed with increasing storage temperature but $t_{1 / 2}$ values decreased. The $t_{1 / 2}$ value of anthocyanins was much shorter at room temperature than at cold storage. Silmilarly, the stability of black carrot anthocyanins at various solid contents between 11$64^{\circ}$ Brix during storage at $4-37^{\circ} \mathrm{C}$ [8] and the stability of anthocyanins in berry juices stored at 4,9 and $21{ }^{\circ} \mathrm{C}$ [13].

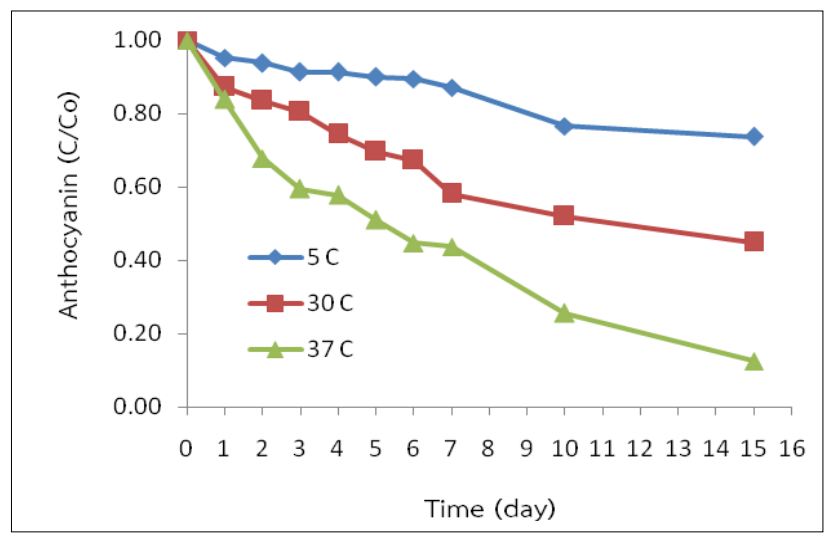

Figure 1. Relation between anthocyanin content $(\mathrm{C} / \mathrm{Co})$ and time (day) of Mao juice at 5,30 and $37{ }^{\circ} \mathrm{C}$; where $\mathrm{C} / \mathrm{Co}$ as ratio of anthocyanins and initial content.

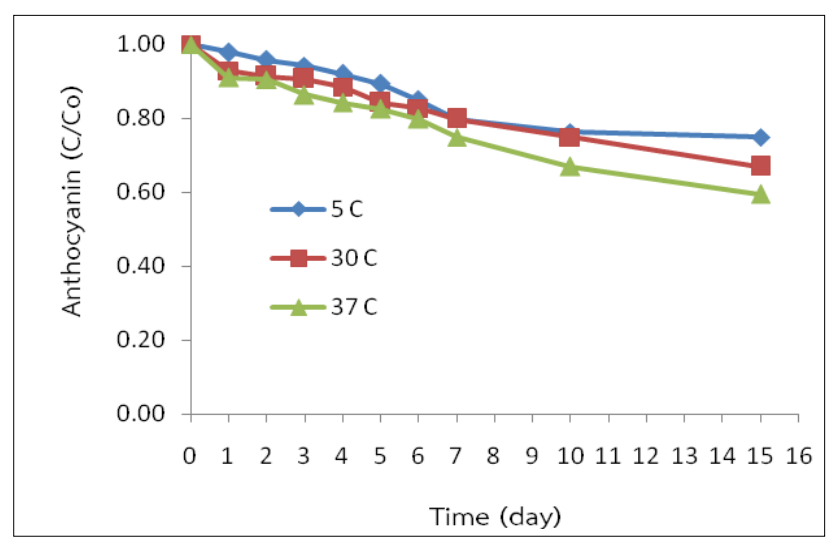

Figure 2. Relation between anthocyanin content $(\mathrm{C} / \mathrm{Co})$ and time (day) of Mao concentrate at 5,30 and $37{ }^{\circ} \mathrm{C}$; where $\mathrm{C} / \mathrm{Co}$ as ratio of anthocyanins and initial content.

In this study, increasing solid content resulted in a slower degradation of anthocyanins during storage. Similar trends were observed for black carrot anthocyanin [8] and blood orange anthocyanins [9]. However, Wang and $\mathrm{Xu}$ [10] found that anthocyanins degraded much faster in blackberry concentrate $\left(65^{\circ} \mathrm{Brix}\right)$ than in blackberry juice $\left(8.9^{\circ} \mathrm{Brix}\right)$ during storage at 5$37^{\circ} \mathrm{C}$.

The stability of anthocyanins depends on type and structure of anthocyanins, origin of juice including polysacharides in fruit. These factors might be attributed to the degradation rate and $t_{1 / 2}$ value of anthocyanins in various juice and concentrate.

Table 2. Effect of storage temperature on the rate constant (k), half life $\left(\mathrm{t}_{1 / 2}\right)$ of anthocyanins degradation in Mao juice and concentrate

\begin{tabular}{|c|c|c|c|}
\hline Sample & $\begin{array}{l}\text { Temp } \\
\left({ }^{\circ} \mathrm{C}\right)\end{array}$ & $\begin{array}{l}\mathrm{k} \times 10^{2} \\
\left(\text { day }^{-1}\right)\end{array}$ & $\begin{array}{c}\mathrm{t}_{1 / 2} \\
\text { (days) }\end{array}$ \\
\hline \multirow{3}{*}{ Juice } & 5 & $2.00(0.94)^{*}$ & 35 \\
\hline & 30 & $5.30(0.96)$ & 13 \\
\hline & 37 & $13.20(0.99)$ & 5 \\
\hline \multirow{3}{*}{ Concentrate } & 5 & $2.20(0.91)$ & 32 \\
\hline & 30 & $2.80(0.98)$ & 25 \\
\hline & 37 & $3.30(0.98)$ & 21 \\
\hline
\end{tabular}

* Numbers in parentheses are the determination coefficients

Kirca et al. [8] studied stability of black carrot anthocyanins during storage at $4-37{ }^{\circ} \mathrm{C}$. The degradation 
fitted a first-order reaction while as anthocyanins decreased with increasing solid content during storage. Higher $\mathrm{E}_{\mathrm{a}}$ values were obtained during storage with increasing solid content.

\subsection{Temperature dependence}

To determine the effect of temperature on the parameter studies, the constants obtained from Eq. (5) were fitted to an Arrhenius-type equation. The dependence of the degradation of Mao juice and concentrate anthocyanins on temperature was shown in Figure 3. At 5, 30 and $37^{\circ} \mathrm{C}$, the calculated activation energy $\left(\mathrm{E}_{\mathrm{a}}\right)$ (Table 3$)$. The result showed that Mao juice has higher $E_{a}$ value than concentrate. High $\mathrm{E}_{\mathrm{a}}$ value implied that the degradation of anthocyanins in Mao juice was more susceptible to temperature elevation than those in concentrate. Similar to results were observed for black carrot anthocyanins [8] and blackberry anthocyanins [10].

Temperature coefficient $\left(\mathrm{Q}_{10}\right)$ was calculated from Eq. (6). The higher $\mathrm{Q}_{10}$ value also obtained for anthocyanins in juice samples. The results clearly indicated the concentration and low temperature storage are able to prevent the degradation of anthocyanins in Mao juice and concentrate.

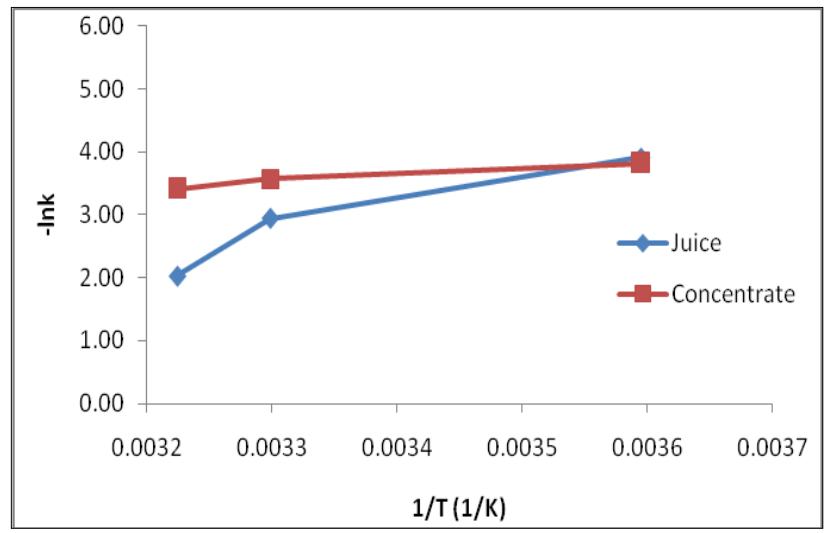

Figure 3. The Arrhenius plots for degradation of anthocyanins in Mao juice and concentrate during storage at 5,30 and $37^{\circ} \mathrm{C}$

Table 3. Effect of storage temperature on activation energy $\left(E_{a}\right)$ and Temperature coefficient $\left(\mathrm{Q}_{10}\right)$ of anthocyanins degradation in Mao juice and concentrate

\begin{tabular}{|c|c|c|c|}
\hline \multirow[t]{2}{*}{ Sample } & \multirow{2}{*}{$\begin{array}{c}\mathrm{E}_{\mathrm{a}} \\
(\mathrm{kJ} / \mathrm{mol})\end{array}$} & \multicolumn{2}{|c|}{$\mathrm{Q}_{10}$} \\
\hline & & $5-30^{\circ} \mathrm{C}$ & $30-37{ }^{\circ} \mathrm{C}$ \\
\hline Juice & 38.03 & 1.48 & 3.69 \\
\hline Concentrate & 8.42 & 1.10 & 1.26 \\
\hline
\end{tabular}

\section{Conclusions}

The kinetic degradation of anthocyanins in Mao juice and concentrate followed a first-order reaction during storage at $5-37^{\circ} \mathrm{C}$. The Stability of Mao anthocyanins depended on storage temperature and solid content. Increasing anthocyanin degradation increased with increasing storage temperature but $t_{1 / 2}$ values decreased. The $t_{1 / 2}$ value of anthocyanins was much shorter at room temperature than at cold storage. Increasing solid content resulted in a slower degradation of anthocyanins during storage. Mao juice has higher $\mathrm{E}_{\mathrm{a}}$ and $\mathrm{Q}_{10}$ value than concentrate. Thus higher stability of anthocyanins was achieved by using concentration and storage at lower temperature. In this study, the kinetic stability could be used to predict the anthocyanins degradation in Mao juice and concentrate during storage.

\section{Acknowledgments}

The authors would like to express their sincere appreciation to Kasetsart University Research and Development Institute (KURDI) and Faculty of Natural Resource and Agro-Industry, Kasetsart University Chalermphrakiat SakonNakhon Provinces Campus for supporting financially.

\section{References}

1. D. Puangpronpitag, P. Areejitranusorn, P. Boonsiri, M. Suttajit, P. Yongvanit, J Food Sci 73, 6 (2008)

2. N. Nuengchamnong, K. Ingkaninan, Food Chem 118, 6 (2010)

3. D. Puangpronpitag, P. Yongvanit, P. Boonsiri, M. Suttajit , P. Areejitranusorn , H.K. Na, Y.J. Surh, Food Chem 127, 9 (2011)

4. Q. Du, J. Zheng, Y. Xu, J Food Comp Anal 21,6 [2008]

5. P. Aramwit, N. Bang, T. Srichana, Food Res Int 43, 5 [2010]

6. P.J. Tsai, L. Delva, T.Y. Yu, Y.T. Huang, L. Dufossé, Food Res Int. 38, 7 [2005]

7. C. Shao-qian,L. Liang, P. Si-yi, Agri Sci China 10, 6 [2011]

8. A. Kirca, M. Ozkan, B. Cemeroğlu, Food Chem 101, 7 (2007)

9. A. Kirca, B. Cemeroğlu, Food Chem 81, 5 (2003)

10. W.D. Wang, S.Y. Xu, J Food Eng 82, 5 (2007)

11. S. Kara, E.A. Erçelebi, J Food Eng 116, 7 (2013)

12. C. Shao-qian, L. Liang, P. Si-yi, Agri Sciences in China 10, 12 (2011)

13. J. Hellström, P. Mattila , R. Karjalainen, J Food Comp Anal 31, (2013)

14. D. Kilcast , P. Subramaniam, New York;CRC press (2000)

15. J. Deng, W. Cheng, G. Yang, Food Chem 125, 4 (2011)

16. A. Kirca, M. Özkan, B. Cemeroğlu, Food Chem 97, 8 (2006) 